$1 G-09$

\title{
看護労働に関するアンケート調査
}

一ベッドー車椅子移動・移乗動作における重労働部分について一

○大久保祐子, 小長谷百絵 (自治医科大学看護短期大学)

小川籍一, 守安貴彦, 池畑 弘, 小野寺直樹 (東京電機大学)

\section{Questionnarire Survey for Nursing Heavy Duties}

- On the hard works for shifting a patient from a bed to a wheel chair Yuko Okubo, Momoe Konagaya (Jichi medical School.,School of Nursing)

Koichi Ogawa, Takahiko Moriyasu, Hiroshi Ikehata, Naoki Onodera (Tokyo Denki University)

\section{1.はじめに}

高齢化社会が進み、健康な老人ばかりでなく日 常生活動作においても全介助・半介助を必要とす る老人も増えている。その中で、看護・介護力の 提供者は筋力の弱い女性であることが多いという 現状があり、介護提供者の負担の軽減が求められ ている。

それらをふまえ、1994年10月に「看護力労働に 係わる看護職員・介護職員へのアンケート調査」 を実施した。本稿は、ベッドー車椅子間の移乗とそ れに関連した動作を中心に、腰痛を引き起こした ことのある動作についての回答と、重労働だと感 じている場面・動作について整理した結果につい て述べる。

\section{2.ベッドー車椅子移動動作で腰痛を起}

\section{こした場面について}

アンケートは、現場看護者 500 人を対象に行い、 357 人から回答を得た。回答者の男女構成、年龄構 成は図1、2のようである。

\section{図.1男女搆成図.2 年落搆成}

男性 (2.8\%)
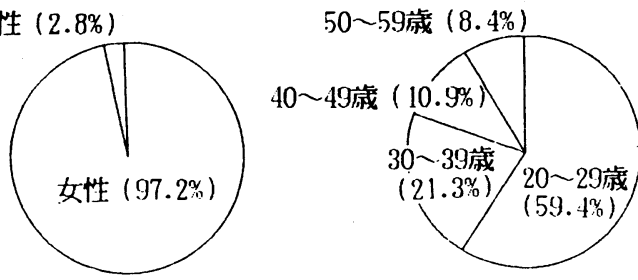

腰痛経験者は75.4\%(269人)であつた。ベッドー車 椅子問の移乗とそれに関連した動作を、図にした ものを示し、その中に腰痛を起こした動作がある か、腰痛を起こした頻度の高い順に3つ選んでも らつた。その結果、腰痛経験者のうち79人は、横
から全面介助で抱き起こす際に腰痛になった経験 があった。次いで、寝たままの対象者を抱きかか える動作、ベッド端に座つている対象者を腋の下 に手を回し抱きかかえる動作で、腰痛を起こした 経験者が51人、45人と多かった。また、ベッドー車 椅子間の移動にかかわる動作をグループとしてみ ると、抱きかかえて車椅子へ移す一連の動作群で、 最も腰痛の発生頻度が高かつた。

\section{図.3 看讙動作場面集（抜粋）}

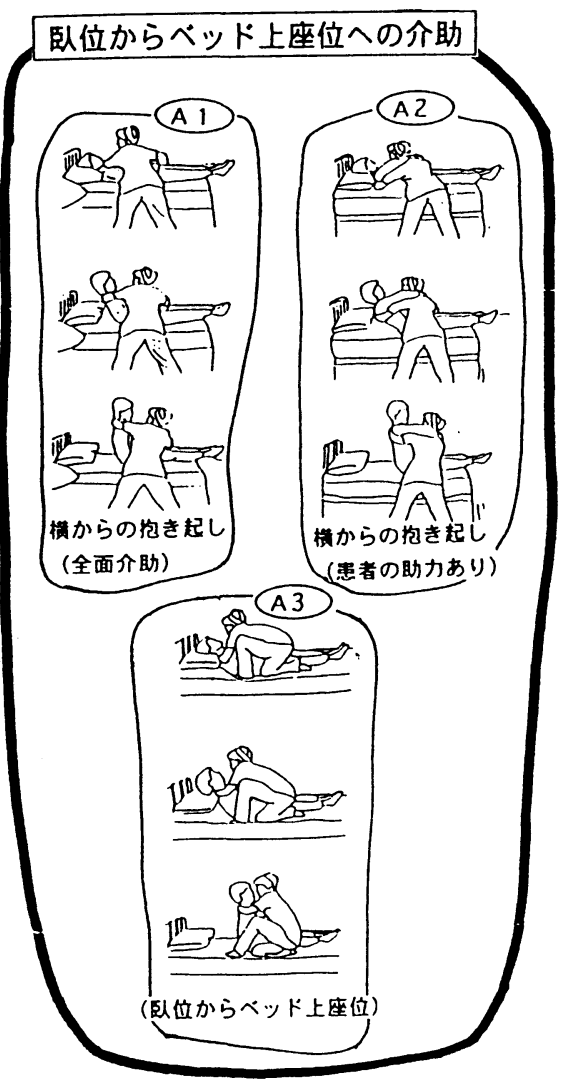


図.4磨痛を起こした動作

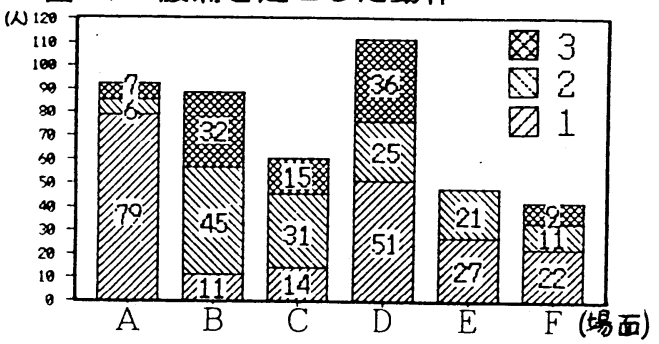

表. 1 看讙動作場面集

A 臥位からべッド上座位への介助 (図3参照)

B 座位から立位への介助

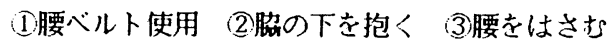

C 立位から車椅子への介助

(1腰ベルト使用 (2亚の下を抱く、腰をはさむ

D 抱きかかえ移乗

(1寝たまま持ち上げる (2)移動する (3)車椅子へ 降万す

E＼cjkstart車椅子からのずり落ちを直す

(1後ろから引く (2)前から押し上げる

F 臥位から端座位への介助

(1)回転させながら起こす (2起こしてから足を降 万す (3)半分足を降ろして起こす

これは、患者を車椅子へ抱きかかえる動作は、 患者の重さが、そのまま介助者の負担になる行為 のためと考えられる。その中でも、抱き上げると きが、腰痛発生頻度が高かった。また、全面介助 の臥床患者をベッド上座位にする動作で、腰痛を 起こしたという回答が最も多かったことは、動作 の実施頻度が高いことと、力の向きが介助者にと って不自然で負担の多い方向であったり、予想以 上に力が必要だったりするするためと考えられる。

\section{3. 重労働と認嘠している場面について}

腰痛経験を問わず、重労働と思う場面を自由記 述で回答してもらった。その結果の概要は以下の ようである。

\section{A. 行為について}

日常生活援助のほとんどの項目が回答にあげら れていた。

1)車椅子への移乗、それに付随する抱き起こし

2)ストレッチャーへの移動、ストレッチャーでの 搬送

3)車椅子からトイレへの移動、トイレでの座りな おし
4)ベッド上での日常生活介助

体位変換、おむつ交換、便器挿入、清拭、洗髪、

更衣、シーツ交換、食事介助）

5)ベッド上でのずり落ちを直す

6) 入浴介助

7)機械・器具の移動・運搬

B. 姿勢

単一の姿勢を続けること、また、動作の頻度の 多さに由来する姿勢の変化の反復運動が、あった。 1)中腰

2)前傾姿勢

3)立位一しゃがみ込みの繰り返し

C. 対象の条件

1) 全面介助の必要な人（寝たきり患者、麻瘏患者、 介助者につかまれない人)

2)肥满者、体格のいい人

3)床にいる患者

D. 介助者の条件

1)一人で介助する

2)女性だけで介助する

3)夜勤のとき、疲れているとき

\section{4.まとめ}

看護労働の中には、重労働と思われる場面が全 般にわたつてあることがわかった。介助者は、多 くの場面で、重労働であると自覚しながら、介助 を提供していた。さらに、看護労㗢の中には、機 械・器具の移動や運搬等、人以外の対象に対する、 重労働も存在している。

一般に病院などの施設では、ベッド生活を送っ ているが、ディールーム・浴室など、介助者の足 下に被介護者がいる環境も少なくなく、そのこと を重労働と感じている人もおり、今後の家庭内介 護の広まりを考えると、介護者への援助の必要性 が示唆された。

病院内で、最も頻繁に行われていると思われる、 ベッドー車椅子間の移動の周辺動作については、全 面介助で横から抱き起こす際に腰痛を起こす介助 者が多く、介助者の面から、力を効率的に使い、 腰痛障害を発生させない方法を開発する必要性が ある。さらに、意識障害など全面介助患者が多く、 必ずしも複数で介助ができるとは限らない環境で 筋力の弱い介助者の補助をする器具・㙨器等の開 発の方向性を見いだした。 